\title{
PENGEMBANGAN PERANGKAT PEMBELAJARAN MENGGUNAKAN MODEL PEMBELAJARAN SCIENCE TECHNOLOGY SOCIETY UNTUK MENINGKATKAN LITERASI SAINS
}

\author{
Luthfia Ulva Irmita \\ Universitas Islam Negeri Raden Fatah Palembang \\ E-mail: luthfiaulvairmita_uin@
}

\begin{abstract}
Abstrak: Penelitian ini bertujuan untuk mengembangkan perangkat pembelajaran menggunakan model pembelajaran Science Technology Society (STS) untuk meningkatkan literasi sains siswa. Perangkat pembelajaran berupa RPP dan LKS pembelajaran. Metode penelitian ini adalah Research and Development yang terdiri dari tiga tahap yaitu pendefinisian, perancangan dan pengembangan. Pada tahap pendefinisian dilakukan persiapan studi awal. Pada tahap perancangan dilakukan untuk menentukan indikator, tujuan pembelajaran dan analisis materi laju reaksi. Pada tahap pengembangan dilakukan pengembangan langkah-langkah kegiatan pembelajaran pada RPP dan LKS pembelajaran dengan menggunakan model STS dengan sintak ekplorasi, pembentukan dan pengembangan konsep, aplikasi konsep, pemantapan dan penilaian. Selanjutnya akan diuji kelayakannya oleh dua orang dosen validator dan dua orang guru kimia SMA. RPP dan LKS pembelajaran dikembangkan untuk meningkatkan literasi sains yang mencakup ketiga aspek yaitu aspek konteks sains, konten sains dan proses sains. Hasil uji kelayakan menunjukkan bahwa perangkat pembelajaran dikatakan memiliki kelayakan yang tinggi dengan rata-rata nilai Aiken's $V$ untuk RPP yaitu 0,697 dan untuk LKS yaitu 0,644. Dengan demikian, perangkat pembelajaran menggunakan model STS dapat digunakan khususnya pada materi laju reaksi kimia.
\end{abstract}

Kata kunci: model STS, literasi sains, laju reaksi

\section{PENDAHULUAN}

Standar proses pendidikan dasar dan menengah pada kurikulum 2013 mengamanatkan bahwa proses pembelajaran pada satuan pendidikan diselenggarakan secara interaktif, inspiratif, menyenangkan, menantang, memotivasi peserta didik untuk berpartisipasi aktif, serta memberikan ruang yang cukup bagi prakarsa, kreativitas dan kemandirian sesuai dengan bakat, minat dan perkembangan fisik serta psikologis peserta didik (Kemdikbud, 2013). Kompetensi mata pelajaran kimia menurut Kurikulum 2013 mancangkup aspek produk, proses, dan sikap. Kompentensi produk meliputi penguasaan terhadap materi yang diajarkan. Kompetensi proses yaitu berupa keterampilan meliputi keterampilan abstrak dan konkret. Keterampilan abstrak, yaitu: menyaji, mengolah, menalar, dan mencipta dengan dominan pada kemampuan mental (berpikir) tanpa bantuan alat. Adapun keterampilan konkret cenderung pada kemampuan fisik seperti menggunakan alat, mencoba, membuat, memodifikasi, dan mencipta dengan bantuan alat. Kompetensi sikap meliputi sikap spiritual dan sosial (BSNP, 2006: 177).

Hasil observasi yang dilakukan di SMAN 2 Banguntapan dan SMAN 1 Pleret pada proses pembelajaran kimia materi termokimia, proses pembelajaran masih didominasi oleh guru sebagai sumber belajar. Guru lebih menekankan pada proses penyelesaian soal-soal dan latihan soal Ujian Nasional (UN). Siswa terkadang melakukan diskusi dan tanya jawab, namun aktivitas siswa lebih banyak mendengarkan dan mencatat. Selain itu, berdasarkan hasil wawancara dua orang guru kimia, sebagian besar proses pembelajaran masih didominasi oleh guru. Pembelajaran kimia kurang melatihkan siswa untuk dapat menggunakan 
kemampuan sainsnya dalam kehidupan sehari-hari, hal ini didukung oleh data dari OECD PISA yang menyatakan rendahnya literasi sains siswa (OECD, 2016).

Berdasarkan hasil observasi dan penilaian oleh PISA, perlu dikembangkan perangkat pembelajaran untuk meningkatkan literasi sains siswa. Perangkat pembelajaran yang terdiri dari RPP dan LKS pembelajaran disusun berdasarkan KD dan KI pada kurikulum 2013 dengan menggunakan model STS dengan sintaks ekplorasi, pembentukan dan pengembangan konsep, aplikasi konsep, pemantapan dan penilaian diharapkan dapat meningkatkan literasi sains siswa. Model pembelajaran STS merupakan paradigma baru dalam pembelajaran sains karena proses pembelajaran berpusat pada siswa untuk menyelidiki dan menganalisis sains dan teknologi, serta hubungannya dengan masyarakat (Aikenhead, 2009). Hasil penelitian Akcay \& Akcay (2015) menyatakan bahwa pembelajaran menggunakan model STS dilakukan dengan memberi kesempatan kepada siswa untuk mengidentifikasi masalah atau isu dari kehidupan sehari-hari untuk diselidiki. Siswa didorong untuk menyelesaikan masalah serta menerapkan konsep dalam penyelesaian masalah sehari-hari. Situasi tersebut dapat meningkatkan kreativitas siswa, berpikir kritis dan meningkatkan keterampilan pemecahan masalah serta mengembangkan sikap yang lebih positif terhadap ilmu pengetahuan untuk mendorong siswa untuk berfikir secara komperhensif. Sehingga diharapkan literasi sains siswa dapat berkembang.

Literasi sains merupakan pengetahuan yang digunakan oleh individu yang berhubungan dengan kehidupan sehari-hari (Carreria, Amado, \& Lecoq, 2011). Köseoğlu (Zan \& Seçken, 2015) menjelaskan bahwa melek sains atau literate terhadap sains berarti mengerti sifat dari ilmu pengetahuan dan perkembangan ilmiah; memahami konsep dasar ilmu pengetahuan, prinsip, hukum, dan teori serta menggunakan pengetahuan dengan cerdas; menggunakan proses ilmiah ketika memecahkan masalah atau membuat keputusan; memahami hubungan antara ilmu pengetahuan dan teknologi, dan ilmu pengetahuan dan lingkungan serta interaksinya dengan masyarakat.

Materi pembelajaran kimia salah satunya yaitu laju reaksi. Materi laju reaksi banyak berhubungan dengan kehidupan sehari-hari. Materi laju reaksi merupakan materi yang mempunyai karakteristik konkrit dan contoh yang konkrit. Materi laju reaksi membutuhkan pembuktian melalui percobaan dengan meminta siswa untuk menyelidiki, menganalisis, dan menyimpulkan (Ilaah dan Yonata, 2015). Kegiatan siswa tersebut dikaitkan dengan contoh kehidupan sehari-hari, sehingga siswa dapat memahami hubungan materi laju reaksi sebagai suatu pengetahuan sains yang dikembangkan dengan teknologi, serta mampu mengkonstruksi pengetahuan yang dimilikinya untuk memecahkan masalah akibat laju dari suatu reaksi terhadap masyarakat dan lingkungan sekitar.

Masalah atau fenomena dalam kehidupan sehari - hari yang disajikan dalam pembelajaran yaitu laju reaksi pembusukan pada buat dan sayuran, laju reaksi pematangan sate yang dipotong tipis dan tebal, laju reaksi pengembangan adonan kue dan laju reaksi penambahan konsentrasi detergen saat mencuci pakaian. Pembelajaran dengan model STS membawa siswa untuk terlibat dalam menganalisis isu yang terjadi di kehidupan sekitar melalui diskusi dengan teman sebaya (Auteri, Amirshokoohi, \& Kazempour, 2016). Selain itu, model 
pembelajaran STS menitikberatkan pada penyelidikan yang dilakukan oleh siswa, sehingga siswa memiliki pengalaman untuk menganalisis isu yang berhubungan dengan kehidupan sehari-hari sehingga mengembangkan keterampilan siswa dengan meningkatkan interaksi, sehingga proses pembelajaran menjadi lebih aktif (Smitha \& Aruna, 2014).

\section{METODE PENELITIAN}

Metode yang digunakan dalam penelitian ini adalah perencanaan dan pengembangan (Research and Development) yang terdiri dari tiga tahap, yaitu define (pendefinisian), design (perancangan) dan develop (pengembangan). Pada tahap define dilakukan studi pendahuluan yaitu observasi pada proses pembelajaran dan wawancara terhadap guru kimia SMA. Pada tahap design yaitu persiapan dalam membuat RPP dan LKS pembelajaran yaitu menentukan kompetensi inti (KI) dan kompetensi dasar (KD) sesuai kurikulum 2013, menentukan indikator, tujuan pembelajaran dan analisis materi laju reaksi. Pada tahap develop dilakukan pengembangan langkah-langkah kegiatan pembelajaran pada RPP dan LKS pembelajaran yang akan diuji kelayakannya oleh dua orang dosen validator dan dua orang guru kimia SMA.

Teknik pengumpulan data yang digunakan berupa angket uji kelayakan yang diberikan kepada dua orang dosen validator dan dua orang guru kimia SMA. Angket kelayakan RPP dan LKS masing-masing terdiri dari 13 pernyataan dengan skala 5 yaitu kategori sangat baik, baik, cukup, kurang, sangat kurang serta kolom saran untuk perbaikan perangkat pembelajaran. Penyataan berisi kejelasan, kesesuaian dan kelengkapan dari perangkat pembelajaran menggunakan model pembelajaran STS.

Teknik analisis data untuk uji kelayakan perangkat pembelajaran dilakukan dengan menggunakan statistik Aiken's $V$. Perangkat pembelajaran yang sudah dinilai oleh dua dosen validator dan dua guru kimia SMA. Data yang diperoleh berupa skor pada skala 1-5 kemudian diubah menjadi nilai Aiken's $V$. Rumus yang ditunjukkan oleh Aiken dalam Azwar (2012: 113) dijelaskan pada Persamaan 1 dan 2.

$$
\begin{array}{r}
V=\Sigma \frac{S}{[n(c-1)]} \\
\mathrm{S}=\mathrm{r}-\mathrm{lo}
\end{array}
$$

\footnotetext{
Keterangan

Lo = angka penilaian validitas yang terendah

$\mathrm{c} \quad=$ angka penilaian validitas tertinggi

$\mathrm{r} \quad=$ angka yang diberikan oleh penilai

$\mathrm{n} \quad=$ jumlah penilai
}

Pengujian kelayakan yang dilakukan dengan perhitungan statistik Aiken's $V$ kemudian dikonversi ke dalam skala 5 untuk melihat kriteria validitas dari instrumen yang dikembangkan. Kriteria kelayakan skala lima dengan menggunakan perhitungan Aiken's $V$ disajikan pada Tabel 2. 
Tabel 1. Kriteria Validitas

\begin{tabular}{lll}
\hline No & Hasil Validitas & Kriteria Validitas \\
\hline $\mathbf{1}$ & $0,80<\mathrm{V} \leq 1,00$ & Sangat Tinggi \\
\hline $\mathbf{2}$ & $0,60<\mathrm{V} \leq 0,80$ & Tinggi \\
\hline $\mathbf{3}$ & $0,40<\mathrm{V} \leq 0,60$ & Cukup \\
\hline $\mathbf{4}$ & $0,20<\mathrm{V} \leq 0,40$ & Rendah \\
\hline $\mathbf{5}$ & $0,00<\mathrm{V} \leq 0,20$ & Sangat Rendah \\
\hline
\end{tabular}

\section{HASIL DAN PEMBAHASAN}

Tahap define merupakan tahap awal penelitian. Pada tahap ini dilakukan studi awal yaitu observasi pada proses pembelajaran termokimia dan wawancara terhadap guru kimia SMA. Berdasarkan hasil observasi dan wawancara, sebagian besar pembelajaran kimia masih menekankan pada penyelesaian soal hitungan dan soal Ujian Nasional (UN) sehingga literasi sains siswa kurang berkembang. Literasi sains dibedakan dalam empat dimensi yaitu konten (pengetahuan sains), proses (kompetensi sains), konteks (aplikasi sains) dan sikap sains (Rakhmawan, Setiabudi, \& Mudzakir, 2015; OECD, 2006; OECD, 2013). Hasil observasi dan wawancara menunjukkan bahwa literasi sains siswa masih rendah maka perlu dikembangkan perangkat pembelajaran untuk meningkatkan literasi sains. Tahap design merupakan tahap perancangan yaitu RPP dan LKS pembelajaran disusun berdasarkan KD dan KI kurikulum 2013 dengan model STS. Dalam penelitian ini RPP dan LKS pembelajaran dikembangkan untuk meningkatkan literasi sains yang mencakup ketiga aspek yaitu aspek konteks sains, konten sains dan proses sains. Aspek konteks sains yaitu konteks dalam kehidupan sehari-hari. Aspek konten sains meliputi pengertian laju reaksi, faktor-faktor yang mempengaruhi laju reaksi serta orde reaksi. Aspek proses sains diantaranya mengidentifikasi isuisu ilmiah, menjelaskan fenomena ilmiah dan menggunakan bukti ilmiah. Kerangka perangkat pembelajaran baik RPP maupun LKS disajikan menggunakan sintaks model STS. Perangkat pembelajaran disusun dengan sintak model STS yaitu eksplorasi, membentuk dan mengembangkan konsep, pemantapan konsep dan evaluasi.

Tahap develop merupakan tahap pengembangan perangkat pembelajaran sebagai produk. Produk yang dikembangkan yaitu RPP dan LKS pembelajaran. RPP dan LKS pembelajaran disusun sebanyak 4 kali pertemuan pada materi laju reaksi. Pertemuan pertama membahas konsep laju reaksi kimia, pertemuan kedua membahas teori tumbukan dan pengaruh luas permukaan tehadap laju reaksi, pertemuan ketiga membahas pengaruh suhu dan katalis terhadap laju reaksi dan pertemuan terkahir membahas pengaruh konsentrasi terhadap laju reaksi serta orde reaksi. Kerangka perangkat pembelajaran baik RPP maupun LKS disajikan menggunakan sintaks model STS. Pada tahap pertama yaitu eksplorasi siswa diperkenalkan dengan isu atau masalah dalam kehidupan sehari-hari dalam bentuk gambar, berita atau fenomena sehingga siswa dapat memusatkan perhatian terhadap apa yang akan dibahas pada proses pembelajaran. Pada tahap kedua yaitu membentuk dan mengembangkan konsep. Siswa berdiskusi dan menjawab pertanyaan yang disajikan oleh guru berdasarkan isu atau masalah yang disajikan. 
Pada tahap ini siswa juga mencari dan menambah informasi untuk lebih mengembangkan konsep. Tahap ketiga yaitu pemantapan konsep. Pada tahap ini siswa berdiskusi dan guru memberikan konfirmasi terhadap pengetahuan yang siswa peroleh agar tidak terjadi kesalahan konsep. Selanjutnya siswa dan guru merumuskan kesimpulan berdasarkan proses pembelajaran yang telah dilakukan. Pada tahap akhir pembelajaran dilakukan evaluasi individu.

Uji kelayakan perangkat pembelajaran dilakukan oleh dua orang dosen validator dan dua orang guru kimia SMA. Pengujian kelayakan perangkat pembelajaran dilakukan dengan perhitungan statistik Aiken's $V$ yang kemudian dikonversi ke dalam skala 5. Data hasil perhitungan kelayakan perangkat pembelajaran berdasarkan Aiken's $V$ disajikan pada Tabel 5.

Tabel 2. Hasil Uji Kelayakan Perangkat Pembelajaran Berdasarkan Aiken's $V$

\begin{tabular}{llll}
\hline No & $\begin{array}{l}\text { Jenis } \\
\text { Perangkat }\end{array}$ & Aiken's $\boldsymbol{V}$ & $\begin{array}{l}\text { Kriteria } \\
\text { Validitas }\end{array}$ \\
\hline $\mathbf{1}$ & RPP & 0,697 & Tinggi \\
\hline $\mathbf{2}$ & $\begin{array}{l}\text { LKS } \\
\text { pembelajaran }\end{array}$ & 0,644 & Tinggi \\
\hline Rata-Rata & $\mathbf{0 , 6 7 0}$ & Tinggi \\
\hline
\end{tabular}

Berdasarkan Tabel 5, nilai Aiken's $V$ untuk RPP yaitu 0,697 berada pada kriteria validitas tinggi. Nilai Aiken's $V$ untuk LKS pembelajaran yaitu 0,644 berada pada kriteria validitas tinggi. Saran perbaikan peragkat pembalajaran dari dua dosen validator dan dua guru kimia SMA diperbaiki dan dikonsultasikan kembali. Saran perbaikan diantaranya yaitu pertanyaan pada LKS di tahap aplikasi konsep kurang mengarahkan siswa untuk dapat menjawab pertanyaan sesuai dengan maksud peneliti. Selain itu, pada RPP di tahap eksplorasi kurang mengajak siswa untuk mengidentifikasi masalah yang disajikan. Terdapat banyak saran perbaikan yang membangun dari segi kejelasan dalam pertanyaan dan telah diperbaiki.

Dalam RPP terdapat kegiatan praktikum, guru meminta siswa untuk menyelidiki, menganalisis, dan menyimpulkan hasil percobaan tersebut. Pembelajaran kimia menggunakan model STS melibatkan siswa secara langsung dalam proses pembelajaran yaitu melakukan praktikum langsung akan sangat efektif dan dapat meningkatkan keterampilan proses sains serta prestasi siswa Alkan (2016).

RPP dan LKS yang disusun menggunakan model STS menganut teori belajar konstruktivisme. Teori konstruktivisme merupakan kegiatan siswa untuk mengkonstruksi pengetahuan berdasarkan pengalaman belajar siswa (Bada \& Olusegun, 2015). Pengalaman belajar siswa diperoleh dengan mencari dan membaca artikel yang berhubungan dengan fenomena, melakukan praktikum, dan mengaplikasikan konsep yang telah dimiliki ke dalam situasi baru. Selain itu, siswa juga mampu memahami dan menerapkan pengetahuan yang dimiliki dalam kehidupan sehari-hari secara tepat dan efektif, dan memiliki kemampuan komunikasi (Thummathong \& Thathong, 2016; Makrs \& Eilks, 2009). Sehingga diharapkan literasi sains siswa dapat berkembang. Hal ini sesuai hasil penelitian 
Hayati, Sutrisno, \& Lukman (2014) menyatakan bahwa pembelajaran dengan menggunakan eksplorasi lebih efektif dibandingkan pengajaran tradisional dalam memunculkan proses kognitif "mendalam" (intuitif). Hasil penelitian Rakhmawan, Setiabudi, \& Mudzakir (2015) mengatakan bahwa pembelajaran literasi sains berbasis inkuiri dalam bentuk kegiatan laboratorium mampu meningkatkan literasi sains siswa pada aspek konten, konteks, proses dan sikap sains siswa pada submateri pokok sel volta.

Pada LKS pembelajaran dilengkapi dengan LKS praktikum. Dalam LKS praktikum terdapat prosedur percobaan serta pertanyaan-pertanyaan. Pembelajaran laju reaksi sebaiknya dilaksanakan terintegrasi antara materi dengan praktikum agar dapat meningkatkan literasi sains hal ini sesuai dengan pendapat Wulandari \& Sholihin (2016) mengatakan bahwa kemampuan literasi sains siswa pada aspek konten dan kompetensi (proses sains) dapat dioptimalkan melalui penerapan pembelajaran berbasis kegiatan praktikum. Ketika siswa berinteraksi dengan lingkungan melalui permasalahan atau fenomena yang disajikan, secara tidak langsung mereka telah terlibat dalam suatu proses pengembangan keterampilan berpikir dan pengembangan literasi sains siswa (Ardianto \& Rubini, 2016).

\section{KESIMPULAN}

Perangkat pembelajaran menggunakan model STS materi laju reaksi disusun berdasarkan KI dan KD pada kurikulum 2013 dan menggunakan sintaks eksplorasi, membentuk dan mengembangkan konsep, pemantapan konsep dan penilaian. Untuk meningkatkan literasi sains materi laju reaksi memiliki kelayakan yang tinggi berdasarkan nilai Aiken's $V$.

\section{DAFTAR RUJUKAN}

Aikenhead, G. S. (2009). Research into STS. Revista Brasileira de Pesquisa em Educação em Ciências, 9(1).

Akcay, B., \& Akcay, H. (2015). Effectiveness of Science-Technology-Society (STS) Instruction on Student Understanding of The Nature of Science and Attitudes Toward Science. International Journal of Education in Mathematics, Science and Technology, 3(1), 37-45.

Alkan, F. (2016). Experiential Learning: Its Effects on Achievement and Scientific Process Skills. Journal of Turkish Science Education, 13(2), 1526.

Ardianto, D., \& Rubini, B. (2016). Literasi sains dan aktivitas siswa pada pembelajaran IPA terpadu tipe shared. Unnes Science Education Journal , 5(1), 1153-1159.

Auteri, S. M., Amirshokoohi, A., \& Kazempour, M. (2016). The ScienceTechnology-Society Framework for Achieving Scientific. European Journal of Science and Mathematics Education, 4(1), 75-89. 
Azwar. (2012). Reliabilitas dan validitas (Edisi keempat). Yogyakarta: Pustaka Pelajar.

Bada, \& Olusegun, S. (2015). Constructivism Learning Theory: A Paradigm for Teaching and Learning. IOSR Journal of Research \& Method in Education (IOSR-JRME), 5(6), 66-70.

BSNP. (2006). Panduan Penyusunan Kurikulum Tingkat Satuan Pendidikan Jenjang Pendidikan Dasar dan Menengah. Jakarta: BSNP.

Carreria, S., Amado, N., \& Lecoq, F. (2011). Mathematiical Modelling of Daily Life in Adult Education: Focusing on the Notion of Knowledge. Springer, 199-209.

Hayati, D. K., Sutrisno, \& Lukman, A. (2014). Pengembangan kerangka kerja TPACK pada materi koloid untuk meningkatkan aktivitas pembelajaran dalam mencapai HOTS S iswa. Edu-Sains , 3(1), 53-61.

Ilaah, Y. F., \& Yonata, B. (2015). Keterampilan Berfikir Kritis Siswa SMA Kemala Bhayangkari 1 Surabaya Pada Materi Laju Reaksi Melalui Penerapan Model Pembelajaran Inkuiri. UNESA Journal of Chemical Education, 78-83.

Kemdikbud. (2013). Peraturan Menteri Pendidikan Dan Kebudayaan RI Nomor 65, Tahun 2013, tentang Standar Proses Pendidikan Dasar Dan Menengah.

Marks, R., \& Eilks, I. (2009). Promoting Scientific Literacy Using a Sociocritical and Problem-Oriented Approach to Chemistry Teaching: Concept, Examples, Experiences. International Journal of Enviromental \& Science Education, 4(3), 231-245.

OECD. (2006). Assessing Scientific, Reading and Mathematical Literacy A Framework for PISA 2006. USA: OECD.

OECD. (2013). PISA 2012 Assessment and Analytical Framework. OECD Publishing.

OECD. (2016). PISA High Performers Siangapure. OECD.

Rakhmawan, A., Setiabudi, A., \& Mudzakir, A. (2015). Perancangan pembelajaran literasi sains berbasis inkuiri pada kegiatan laboratorium. Jurnal Penelitian dan Pembelajaran IPA , 1(1), 143-152.

Sani, R. A. (2015). Pembelajaran Saintifik Untuk Implementasi Kurikulum 2013. jakarta: PT Bumi Aksara. 
Smitha, \& Aruna, P. K. (2014). Effect of Science Technology Society Approach on Achievement Motivation in Biology of Secondary School Students of Kasaragod District. IOSR Journal Of Humanities And Social Science (IOSRJHSS), 19(4), 54-48.

Thummathong, R., \& Thathong, K. (2016). Construction of a Chemical Literacy Test for Engineering Students. Journal of Turkish Science Education, 13(3), 185-198.

Wulandari, N., \& Sholihin, H. (2016). Analisis kemampuan literasi sains pada aspek pengetahuan dan kompetensi sains siswa pada materi kolor. jurnal edusains , 8(1), 66-73.

Zan, N., \& Seçken, N. (2015). Monthly Chemistry Newspaper in Vocational High Schools. International J. Soc. Sci. \& Education, 5(4), 746-766. 